\title{
YURISDIKSI PENGAWASAN INTERNAL DAN EKSTERNAL TERHADAP TANGGUNG JAWAB PROFESI HAKIM (ANALISIS KASUS PEMERIKSAAN HAKIM PT BANDUNG TERKAIT SENGKETA PEMILIHAN KEPALA DAERAH KOTA DEPOK)
}

\author{
Andi Ahmad Nur Darwin ${ }^{1}$
}

\begin{abstract}
Abstrak
This article is as a result of normative law research which endeavors to explain regarding ensued case in local head (major) election in Depok town. As the result of Judicial Comission's examination that has issued reccomendation to apply temporary discharged sanctions towards Head of Justice who examined the case. In the author analyze here it doesnot Comission competences because chiefly fall in to decision excellence. The parameter of exelence is considers on legal thoughts (correctness aspects through implementation and legal interpretations;relevance of consideration and the decision), and legal reason's factors. They all are becomes the judicial technical which is more Supreme Court (Mahkamah Agung) competences and adequately not as the Comission holds of.
\end{abstract}

Kata kunci:hukum acara, yurisdiksi pengawasan, profesi hakim, analisis kasus, sengketa pilkada depok

\section{Pendahuluan}

Penyelenggaraan kekuasaan kehakiman diserahkan kepada badanbadan peradilan yang ditetapkan dengan undang-undang dengan tugas pokok untuk menerima, memeriksa, mengadili dan menyelesaikan setiap perkara yang diajukan kepadanya. Dalam ketentuan pasal 10 Undang-Undang No. 4 Tahun 2004 tentang Kekuasaan Kehakiman dinyatakan bahwa penyelenggaraan kekuasaan kehakiman dilakukan oleh sebuah Mahkamah Agung dan badan-badan peradilan yang berada dibawahnya, dan oleh sebuah Mahkamah Konstitusi. ${ }^{2}$ Seperti diketahui bahwa terdapat fungsi-fungsi

'Alumni Fakultas Hukum Universitas Indonesia, Program Reguler Angkatan 2002.

${ }^{2}$ Indonesia (A), Undang-Undang tentang Kekuasaan Kehakiman, UU No. 4 Tahun 2004, LN Tahun 2004 Nomor 8, Pasal 10 angka 1. 
Mahkamah Agung dalam menyelenggarakan kekuasaan kehakiman ada 5 yaitu: ${ }^{3}$

1. Fungsi Peradilan (Justitiele functie);

2. Fungsi Pengawasan (Toeziende functie);

3. Fungsi mengatur (regelende functie);

4. Fungsi Penasehat (advieserende functie);

5. Fungsi Administratif (administratieve functie).

Berdasarkan fungsi Mahkamah Agung dalam menjalankan kekuasaan kehakiman terutama pada fungsi pengawasan bahwa Mahkamah Agung melakukan pengawasan terhadap hakim, maka Mahkamah Agung berwenang dan wajib melakukan pengawasan terhadap lingkungan peradilan dibawahnya. ${ }^{4}$ Adapun badan peradilan yang berada di bawah Mahkamah Agung meliputi badan peradilan dalam lingkungan: ${ }^{5}$

a. Badan Peradilan Umum;

b. Badan Peradilan Agama;

c. Badan Peradilan Militer;

d. Badan Peradilan Tata Usaha Negara.

Kemandirian kekuasaan kehakiman atau kebebasan hakim merupakan asas yang sifatnya universal, yang terdapat dimana saja dan kapan saja ${ }^{6}$. Asas ini berarti bahwa dalam melaksanakan peradilan, hakim itu pada dasarnya bebas, yaitu bebas dalam memeriksa dan mengadili perkara dan bebas dari campur tangan kekuasaan ekstra yudisiil. Suatu kenyataan yang ada, hukum tidak selalu lengkap, sering samar-samar, atau bahkan hukum tidak ada, apabila dihadapkan dengan peristiwa konkrit (kasus) yang sedang dihadapi.

${ }^{3}$ Paulus Effendi Lotulung. "Kemandirian Kekuasaan Kehakiman Dalam Konteks Pembagian Kekuasaan dan Pertanggungan Jawab Politik," (Makalah disampaikan pada seminar Hukum Nasional ke-VIl dengan tema Reformasi Hukum Menuju Masyarakat Madani, Jakarta. 12-15 Oktober 1999), hal. 6-9.

${ }^{4}$ Indonesia (A). Op. Cit., Pasal 11 angka 4 yang berbunyi Mahkamah Agung melakukan pengawasan tertinggi atas perbuatan pengadilan dalam lingkungan peradilan yang berada di bawahnya berdasarkan ketentuan undang-undang.

${ }^{5}$ Ibid., Pasai 10 angka 2.

${ }^{6}$ Bambang Sutiyoso dan Sri Hastuti Puspitasari, “Aspek-Aspek Perkembangan Kekuasaan Kehakiman di Indonesia”, (Yogyakarta: UII-Press, 2005), hal. 51.

${ }^{7}$ Sudikno Mertokusumo, et A. Pitio, "Bab-bab Tentang Penemuan Hukum", cet.1, (Jakarta: PT. Citra Aditya. 1993). Hal. 6, 32, dan 37. Dalam buku beliau yang berjudul tentang "Penemuan Hukum sebuah Pengantar", Penerbit Liberty Jogjakarta. Cet. Kedua, Juni 2001. 
Dalam suasana yang demikian hakim tidak diperbolehkan menolak perkara, ${ }^{8}$ hakim harus memeriksa dan memutus perkara tersebut dengan melakukan penemuan hukum (interpretasi). Bahkan, kalau perlu menggunakan kaidahkaidah hukum yang tidak tertulis.' Hakim dengan inisiatif sendiri, pertimbangan sendiri, menemukan hukum dan memutus perkara yang dihadapi. ${ }^{10}$ Dalam menjalankan kemandiriannya ini, hakim wajib menaati norma hukum yang telah tercantum dalam undang-undang. Disamping itu, masih diperlukan norma yang lain, yaitu norma etika-moral dan bahkan norma agama demi tercapainya suatu penyelenggaraan proses peradilan yang mandiri dan bebas. Oleh karena itu, profesi hakim juga memerlukan kode etik yang mempunyai kekuatan mengikat bagi para anggotanya.

Masalah kemudian timbul ketika para hakim di berbagai tingkat peradilan pada era reformasi ini mulai dipertanyakan kemandiriannya dalam memutus suatu perkara peradilan sehingga muncul berbagai istilah yang berkembang dewasa ini yaitu peradilan kelabu, mafia peradilan, kolusi peradilan dan sebagainya yang menurunkan citra lembaga peradilan. Banyaknya dugaan para hakim yang disuap demi memenangkan pihak tertentu tidak boleh dibiarkan begitu saja oleh Mahkamah Agung sebagai lembaga yang berwenang mengawasi jalannya peradilan di semua lingkungan peradilan di Indonesia. Akan tetapi dalam prakteknya, mekanisme pengawasan hakim yang dilakukan oleh Mahkamah Agung cenderung tertutup dan tidak dipublikasikan kepada umum. Hal ini disebabkan mekanisme pemeriksaan dilakukan secara internal sehingga tidak

hal. 37. mengatakan: "Kegiatan kehidupan manusia itu sangat luas, tidak terhitung jumlah dan jenisnya. sehingga tidak mungkin tercakup dalam suatu peraturan perundang-undangan dengan tuntas dan jelas. Maka wajarlah kalau tidak ada peraturan perundang-undangan yang dapat mencakup keseluruhan kegiatan kehidupan manusia, sehingga tidak ada peraturan perundang-undangan yang lengkap selengkap-lengkapnya dan jelas sejelas-jelasnya. Oleh karena hukumnya tidak lengkap dan tidak jelas. maka harus dicari dan ditemukan".

8 Indonesia (A), Op. Cit., Pasal 16 angka 1, yang berbunyi sebagai berikut: -Pengadilan tidak boleh menolak untuk memeriksa. mengadili, dan memutus sesuatu perkara yang diajukan dengan dalih bahwa hukum tidak ada atau kurang jelas, melainkan wajib untuk memeriksa dan mengadilinya".

"Ibid.. Pasal 28 angka 1, yang berbunyi sebagai berikut: (1) "Hakim sebagai penegak hukum dan keadilan wajib menggali. mengikuti dan memahami nilai-nilai hukum yang hidup dalam masyarakat".

${ }^{10}$ Wiarda. "Drie Typen lan de Rechtsvindings". (Deventer: W.E.J - Tjeink Willink. 1999). hal. 14. Untuk mengatasi kekosongan hukum tersebut, hakim dalam mengadili perkara mempunyai 3 (tiga) fungsi, yaitu: (1). Hakim sebagai corong undang-undang: (2). Hakim sebagai penterjemah undang-undang dengan interpretasi; dan (3). Hakim menggunakan inisiatif sendiri (pertimbangan sendiri), atau otonom. 
Dalam suasana yang demikian hakim tidak diperbolehkan menolak perkara, ${ }^{8}$ hakim harus memeriksa dan memutus perkara tersebut dengan melakukan penemuan hukum (interpretasi). Bahkan, kalau perlu menggunakan kaidahkaidah hukum yang tidak tertulis.' Hakim dengan inisiatif sendiri, pertimbangan sendiri, menemukan hukum dan memutus perkara yang dihadapi. ${ }^{10}$ Dalam menjalankan kemandiriannya ini, hakim wajib menaati norma hukum yang telah tercantum dalam undang-undang. Disamping itu, masih diperlukan norma yang lain, yaitu norma etika-moral dan bahkan norma agama demi tercapainya suatu penyelenggaraan proses peradilan yang mandiri dan bebas. Oleh karena itu, profesi hakim juga memerlukan kode etik yang mempunyai kekuatan mengikat bagi para anggotanya.

Masalah kemudian timbul ketika para hakim di berbagai tingkat peradilan pada era reformasi ini mulai dipertanyakan kemandiriannya dalam memutus suatu perkara peradilan sehingga muncul berbagai istilah yang berkembang dewasa ini yaitu peradilan kelabu, mafia peradilan, kolusi peradilan dan sebagainya yang menurunkan citra lembaga peradilan. Banyaknya dugaan para hakim yang disuap demi memenangkan pihak tertentu tidak boleh dibiarkan begitu saja oleh Mahkamah Agung sebagai lembaga yang berwenang mengawasi jalannya peradilan di semua lingkungan peradilan di Indonesia. Akan tetapi dalam prakteknya, mekanisme pengawasan hakim yang dilakukan oleh Mahkamah Agung cenderung tertutup dan tidak dipublikasikan kepada umum. Hal ini disebabkan mekanisme pemeriksaan dilakukan secara internal sehingga tidak

hal. 37. mengatakan: "Kegiatan kehidupan manusia itu sangat luas, tidak terhitung jumlah dan jenisnya. sehingga tidak mungkin tercakup dalam suatu peraturan perundang-undangan dengan tuntas dan jelas. Maka wajarlah kalau tidak ada peraturan perundang-undangan yang dapat mencakup keseluruhan kegiatan kehidupan manusia, sehingga tidak ada peraturan perundang-undangan yang lengkap selengkap-lengkapnya dan jelas sejelas-jelasnya. Oleh karena hukumnya tidak lengkap dan tidak jelas. maka harus dicari dan ditemukan".

8 Indonesia (A), Op. Cit., Pasal 16 angka 1, yang berbunyi sebagai berikut: -Pengadilan tidak boleh menolak untuk memeriksa. mengadili, dan memutus sesuatu perkara yang diajukan dengan dalih bahwa hukum tidak ada atau kurang jelas, melainkan wajib untuk memeriksa dan mengadilinya".

"Ibid.. Pasal 28 angka 1, yang berbunyi sebagai berikut: (1) "Hakim sebagai penegak hukum dan keadilan wajib menggali. mengikuti dan memahami nilai-nilai hukum yang hidup dalam masyarakat".

${ }^{10}$ Wiarda. "Drie Typen lan de Rechtsvindings". (Deventer: W.E.J - Tjeink Willink. 1999). hal. 14. Untuk mengatasi kekosongan hukum tersebut, hakim dalam mengadili perkara mempunyai 3 (tiga) fungsi, yaitu: (1). Hakim sebagai corong undang-undang: (2). Hakim sebagai penterjemah undang-undang dengan interpretasi; dan (3). Hakim menggunakan inisiatif sendiri (pertimbangan sendiri), atau otonom. 
dikaji secara teoritis mengenai karakteristik Profesi Hakim, tanggung-jawab pelaksanaan jabatan hakim dan pengawasan terhadap Profesi Hakim baik secara internal maupun eksternal.

\section{Tanggung Jawab Profesi Hakim}

\section{A. Karakteristik Profesi Hakim}

Profesi hakim merupakan salah satu profesi di bidang hukum yang menuntut suatu keahlian khusus karena hakim merupakan pelaku inti yang secara fungsional melaksanakan kekuasaan kehakiman. ${ }^{14}$ Dalam melaksanakan kekuasaan kehakiman tersebut, hakim harus memahami ruang lingkup tugas dan kewajibannya. Oleh karena itu profesi hakim memiliki suatu karakteristik yang membedakannya dengan profesi lain. Adapun karakteristik tersebut adalah:

\section{Proses Rekrutmen ${ }^{15}$}

Rekrutmen adalah proses mencari dan menarik orang yang diinginkan oleh organisasi untuk mengisi lowongan pekerjaan tertentu. ${ }^{16}$ Rekrutmen merupakan proses paling awal yang penting dalam pengelolaan sumber daya manusia. Peran penting rekrutmen dirasakan pula bagi jabatan hakim dimana dengan proses ini dapat diharapkan terpenuhinya hakim-hakim yang punya kualitas dan integritas yang tinggi dalam menjalankan profesinya tersebut. berdasarkan Undang-Undang No. 8 Tahun 2004 tentang perubahan atas Undang-Undang No. 2 Tahun 1986 tentang Peradilan Umum pasal 14 angka 1, seseorang hanya dapat diangkat menjadi hakim jika memenuhi persyaratan sebagai berikut: $^{17}$

\footnotetext{
${ }^{14}$ Bambang Sutiyoso dan Sri Hastuti Puspitasari. Op. Cit.. hal. 54.

15 Mahkamah Agung RI, "Kertas Kerja Pembaruan Sistem Pembinaan SDM

${ }^{10}$ B.N Marbun. “Kamus Manajemen”. (Jakarta: Pustaka Sinar Harapan. 2003).

${ }^{17}$ Indonesia (B). Undang-Undang tentang Peradilan U'mum. UU No. 8 Tahun 2004.
} Hakim”. (Jakarta: MARI, 2003), hal. 22. LN Tahun 2004 Nomor 34. Pasal 14 angka 1. 
a. Warga Negara Indonesia;

b. Bertakwa kepada Tuhan Yang Maha Esa;

c. Setia kepada Pancasila dan Undang-Undang Dasar 1945

d. Bukan bekas anggota organisasi terlarang Partai Komunis Indonesia termasuk organisasi massanya atau bukan seorang yang terlibat langsung ataupun tak langsung dalam "Gerakan Kontra Revolusi G.30.S/PKI atau organisasi terlarang lainnya;

e. Pegawai Negeri;

f. Sarjana hukum;

g. Berumur serendah-rendahnya 25 (dua puluh lima) tahun

h. Berwibawa, jujur, adil, dan berkelakuan baik;

Selain persyaratan umum tersebut, Depkeh \& HAM (sekarang Departemen Hukum dan Perundang-Undangan) mengeluarkan pula persyaratan teknis yang harus dipenuhi calon hakim. Bagi calon hakim yang fresh graduate dari Universitas, syarat tersebut antara lain adalah "Sarjana Hukum dari Perguruan Tinggi Negeri/Swasta yang terakreditasi/swasta yang dipersamakan/lulus Ujian Negara dengan Indeks Prestasi (IP) minimal $2,75^{\prime}$.

\section{Pendidikan dan Pelatihan (Diklat) Hakim $^{18}$}

Karakteristik diklat hakim di Indonesia dapat ditandai dengan pelaksanaannya yang ditekankan pada awal jabatan dan keterkaitannya yang sangat erat dengan proses rekrutmen hakim, yaitu selain ditujukan sebagai program orientasi/induksi bagi para calon hakim. juga dipergunakan sebagai media bagi seleksi hakim. Program diklat dimulai dari kewajiban para peserta untuk memenuhi masa magang selama kurang lebih 1 tahun sebagai Calon Pegawai Negeri Sipil (CPNS) di pengadilan-pengadilan negeri di seluruh Indonesia. Pada tahap yang dinamakan Diklat Praktek I ini bisa dikatakan belum ada program pembinaan yang terarah. Para peserta diklat masih sebatas dikaryakan sebagai staf administrasi pengadilan, hingga saatnya mereka mengikuti ujian pra-jabatan, yang merupakan fase seleksi kepegawaian secara umum.

${ }^{18}$ Mahkamah Agung RI. "Kertas Kerja Pembaruan Sistem Pendidikan dan Pelatihan Hakim". (Jakarta: MARI, 2003), hal. 8-9. 
Baru setelah memperoleh status PNS, para peserta akan mengikuti diklat klasikal yang diadakan secara terpusat oleh Pusat Pendidikan dan Latihan (Pusdiklat) Departemen Hukum dan Perundang-Undangan (Depkumdang). Para peserta akan menerima berbagai materi keahlian di bidang hukum, dan mulai dipersiapkan secara teoritis untuk mengemban jabatan sebagai hakim. Begitu dinyatakan lulus, para peserta diharuskan memenuhi masa magang kembali dengan status sebagai calon hakim ke berbagai pengadilan negeri selama sedikitnya 1 tahun. Secara formal tahapan ini disebut Diklat Praktek II, dengan pola pembinaan yang sudah lebih mengarah pada pelaksanaan tugas hakim. Jika dinilai layak, para peserta akan diusulkan oleh Ketua Pengadilan Negeri dimana calon hakim tersebut ditempatkan untuk diangkat penuh sebagai hakim dan pengangkatannya dilakukan oleh Presiden melalui Menteri terkait yaitu Menkumdang.

\section{B. Tanggung Jawab Hakim dalam Menjalankan Tugas}

Terdapat 3 macam tanggung jawab bagi profesi:

tanggung jawab moral

Adalah tanggung jawab sesuai dengan nilai-nilai, norma yang berlaku dalam lingkungan kehidupan profesi yang bersangkutan (kode etik profesi) yang bisa bersifat pribadi maupun kelembagaan (bagi suatu lembaga yang merupakan ikatan/perikatan para aparat/profesi yang bersangkutan).

tanggung jawab teknis profesi

Merupakan tuntunan bagi aparat untuk melaksanakan tugasnya secara profesional sesuai dengan kriteria teknis yang berlaku dalam bidang profesi yang bersangkutan, baik bersifat umum maupun ketentuan khusus yang berlaku dalam lembaga yang bersangkutan. Sanksinya adalah penilaian atas kemampuan (unprofessional conduct).

- tanggung jawab hukum

Adalah tanggung jawab yang menjadi beban aparat untuk dapat melaksanakan tugasnya dengan tidak melanggar rambu-rambu hukum. Wujud pertanggungjawaban hukum adalah sanksi.

Adapun tanggung jawab seorang hakim terhadap profesinya yaitu sebagai penegak hukum dapat dibedakan atas tanggung jawab terhadap 
pribadi hakim, tanggung jawab dalam melakukan tugas jabatan dan tanggung jawab hakim terhadap pihak ketiga (pencari keadilan).

Tanggung jawab hakim terhadap pribadi adalah: ${ }^{19}$

- percaya dan takwa kepada Tuhan Yang Maha Esa:

- menjunjung tinggi citra, wibawa, dan martabat hakim

- berkelakuan baik dan tidak tercela serta menjadi teladan bagi masyrakat;

- menjauhkan diri dari perbuatan asusila dan kelakuan yang tercela;

- tidak melakukan perbuatan yang merendahkan martabat hakim;

- bersikap jujur, adil, penuh rasa tanggung jawab:

- berkepribadian, sabar, bijaksana, berilmu;

- bersemangat ingin maju, dapat dipercaya dan berpandangan luas.

Tanggung jawab hakim dalam melakukan tugas jabatan: ${ }^{20}$

- bersikap tegas, disiplin;

- penuh pengabdian pada pekerjaan dan bebas dari pengaruh siapapun juga;

- tidak menyalahgunakan kepercayaan, kedudukan, dan wewenang untuk kepentingan pribadi atau golongan;

- tidak berjiwa mumpung dan tidak menonjolkan kedudukan

- menjaga wibawa dan martabat hakim dalam hubungan kedinasan serta berpegang teguh pada kode kehormatan hakim;

Tanggung jawab Hakim Terhadap Pihak Ketiga adalah:

- Bersikap dan bertindak menurut garis-garis yang ditentukan dalam Hukum Acara yang berlaku, dengan memperhatikan azas-azas peradilan yang baik, yaitu:

a. Menjunjung tinggi hak seseorang untuk mendapat putusan (right to a decision) dimana setiap orang berhak untuk mengajukan perkara dan dilarang menolak untuk mengadilinya kecuali ditentukan lain oleh undang-undang 2001). hal. 102 .

Abdulkadir Muhammad, "Etika Profesi Hukum”. (Bandung: Citra Aditya Bakti. 
serta putusan harus dijatuhkan dalam waktu yang pantas dan tidak terlalu lama.

b. Semua pihak yang berperkara berhak atas kesempatan dan perlakuan yang sama untuk didengar, diberikan kesempatan untuk membela diri, mengajukan bukti-bukti serta memperoleh informasi dalam proses pemeriksaan ( $a$ fair hearing)

c. Putusan dijatuhkan secara obyektif tanpa dicemari oleh kepentingan pribadi atau pihak lain (no bias) dengan menjunjung tinggi prinsip (nemo judex in resud)

d. Putusan harus memuat alasan-alasan hukum yang jelas dan dapat dimengerti serta bersifat konsisten dengan penalaran hukum yang sistematis, dimana argumentasi tersebut harus diawasi dan diikuti serta dapat dipertanggungjawabkan guna menjamin sifat keterbukaan dan kepastian hukum dalam proses peradilan.

e. Menjunjung tinggi hak-hak azasi manusia

* Tidak dibenarkan menunjukkan sikap memihak atau bersimpati ataupun antipati kepada pihak-pihak yang berperkara, baik dalam ucapan maupun tingkah laku;

- Harus bersifat sopan, tegas dan bijaksana dalam memimpin sidang, baik dalam ucapan maupun dalam perbuatan;

- Harus menjaga kewibawaan dan kehidmatan persidangan antara lain serius dalam memeriksa, tidak melecehkan pihakpihak baik dengan kata-kata maupun dalam perbuatan;

- Bersungguh-sungguh mencari kebenaran dan keadilan.

\section{Sistem Pengawasan Terhadap Hakim}

\section{A. Sistem Pengawasan Internal (Mahkamah Agung)}

Pengawasan dan pendisiplinan hakim merupakan hal yang sangat penting di Indonesia. ${ }^{21}$ Oleh karena itu diperlukan suatu sistem pengawasan dan pendisiplinan terhadap kinerja hakim dalam menghasilkan suatu putusan, termasuk didalamnya bagaimana mekanisme pemeriksaan jika terjadi pelanggaran terhadap kode etik hakim tersebut. sistem ini dijalankan oleh Mahkamah Agung 
berdasarkan fungsinya sebagai Lembaga Pengawasan di Lingkungan Peradilan di Indonesia.

Sebelum membahas mengenai sistem pemeriksaan terhadap hakim yang diduga melanggar kode etiknya, perlu diketahui terlebih dahulu bagaimana mekanisme pengawasan dan pendisiplinan hakim pada masa sistem dua atap dan pada masa sistem satu atap termasuk instrumen yang dipakai pada dua sistem tersebut yang menentukan kapan seorang hakim dapat dikatakan telah atau diduga melanggar kode etik perilaku hakim.

\section{Sistem Pengawasan Dua Atap}

Sebelum adanya sistem penyatuan atap pada tahun 2004 yang ditandai dengan UU No. 4 Tahun 2004 tentang Kekuasaan Kehakiman, sesuai dengan UU No. 14 Tahun 1970, UU No. 2 Tahun 1986, UU No. 5 Tahun 1986, UU No. 7 tahun 1989 dan UU No. 31 Tahun 1997 bahwa pembinaan organisasi, administrasi, dan keuangan pengadilan (termasuk hakim) dilakukan oleh menteri terkait atau Panglima TNI dalam hal peradilan militer. Adanya dualisme pembinaan kekuasaan kehakiman atau lebih dikenal dengan nama sistem dua atap menyebabkan kesulitan melakukan pengawasan pada khusunya karena berdasarkan UU No. 14 tahun 1970 bahwa Mahkamah Agung melakukan pengawasan tertinggi terhadap kekuasaan pengadilan dibawahnya ${ }^{22}$ termasuk dalam hal ini pengawasan terhadap perilaku hakim. Akan tetapi disisi lain, hakim pengadilan tingkat pertama dan tingkat banding kedudukannya sebagai Pegawai Negeri Sipil yang berinduk kepada menteri kehakiman. Mereka terikat dengan sumpah Prasetya Korpri dan peraturan disiplin Pegawai Negeri sipil. Jadi, dapat dikatakan bahwa Departemen Kehakiman memiliki kewenangan untuk melakukan evaluasi kinerja terhadap hakim dalam statusnya sebgai Pegawai Negeri sipil (PNS) dan MA memiliki kewenangan untuk melakukan evaluasi kinerja sebagai Pembina aspek teknis yudisial dan pengawas tertinggi dalam penyelenggaraan pengadilan. ${ }^{23}$ 1985. Pasal 2.

2 Indonesia (C), Undang-lindang tentang Mahkamah Agung, UU No. 14 Tahun

${ }^{23}$ Kertas Kerja Pembaruan Sistem Pembinaan SDM Hakim. Op. Cit, hal. 144. 
Bertolak dari adanya dua evaluasi ini, dapat dilihat bahwa instrumen yang digunakan pun akan berbeda dimana Departemen Kehakiman menggunakan Daftar Penilaian Pelaksanaan Pekerjaan (DP3) berdasarkan PP No. 10 Tahun 1979 mengenai Penilaian Pelaksanaan Pekerjaan Pegawai Negeri Sipil untuk melakukan penilaian terhadap kinerja hakim. Adapun instrumen yang (pernah) digunakan oleh Mahkamah Agung ada beberapa yaitu formulir EVA. I dan WAS.1. selain itu, MA juga memiliki mekanisme eksaminasi putusan untuk menilai kualitas putusan hakim, yaitu:

a. Daftar Penilaian Pelaksanaan pekerjaan (DP 3) atau conduite staat dilakukan secara subyektif oleh atasan langsung dari PNS yang dinilai/dievaluasi dan dilakukan sekali dalam setahun. $^{24}$

Pada hakim pengadilan tingkat pertama, yang menjadi Pejabat Penilai adalah ketua-ketua Pengadilan tingkat pertama. $^{25}$ Atasan pejabat penilai adalah Ketua pengadilan Banding. Dengan sistem dua atap ini, posisi pejabat penilai tertinggi bagi hakim bukanlah Mahkamah Agung melainkan Direktur Jenderal pembinaan Peradilan Umum dan Tata Usaha Negara (Dirjen Badilumtun). ${ }^{26}$ Pemberian penilaian terhadap kinerja PNS ini merupakan diskresi pejabat penilai. Hasil penilaiannya merupakan dokumen yang bersifat rahasia. Jika PNS keberatan dengan penilaian tersebut, maka dapat mengajukan keberatan disertai alasan-alasan kepada Pejabat Penilai dalam tempo 14 hari sejak diterimanya hasil DP3 tersebut. Tujuan daripada DP3 ini sebenarnya digunakan sebagai bahan penilaian yang selanjutnya akan digunakan untuk melaksanakan pembinaan PNS. ${ }^{27}$ Jadi. evaluasi DP3 ini pada dasarnya digunakan untuk evaluasi

24 Indonesia (D). Peraturan Pemerintah mengenai Penilaian Pelaksanaan Pekeraan Pegawai Negeri Sipil. PP No. 10 Tahun 1979, Pasal 2.

25 Berdasarkan hasil wawancara dengan Amin Sutikno. S.H., M.H.. Hakim Pengadilan Negeri Kerawang. Bekasi pada hari minggu. tanggal 4 Desember 2005.

2o Kertas kerja Pembaruan Sistem Pembinaan SDM Hakim, Op. Cit., hal. 148.

Thid. hal. 145. pembinaan PNS yang dimaksudkan antara lain dalam mempertimbangkan kenaikan pangkat. penempatan dalam jabatan. pemindahan, kenaikan gaji berkala dan lain-lain. 
kinerja hakim sebagai PNS atau berdasarkan kemampuan organisasi dan administrasi hakim sebagai Pegawai Negeri Sipil (PNS).

b. Formulir Pengawasan dan Evaluasi Pengawasan (EVA. 1 dan WAS. 1)

Dalam hal pengawasan oleh Mahkamah Agung, instrumen yang digunakan atau yang pernah dimiliki oleh MA adalah Formulir EVA.1 dan WAS.1. mengenai kedua instrumen tesrebut diatur dalam Surat Keputusan Mahkamah Agung No. KMA/005/SK/1994 mengenai Pengawasan dan Evaluasi atas Hasil Pengawasan oleh Mahkamah Agung RI (Formulir Eva.1) dan SK No. KMA/006/SK/III/1994 tentang Pengawasan dan Evaluasi atas Hasil Pengawasan oleh Pengadilan Tingkat Banding dan Pengadilan Tingkat Pertama (Formulir WAS.1).

\section{Mekanisme Pengawasan}

Evaluasi hasil pengawasan terhadap hakim dilakukan secara bertingkat, mulai dari evaluasi yang dilakukan di lingkungan pengadilan tingkat pertama dan tingkat banding sendiri, kemudian evaluasi oleh pengadilan yang lebih tinggi dan berpuncak di Mahkamah Agung. Perlu diperhatikan bahwa instrumen ini hanya berlaku bagi Hakim Pengadilan Negeri dan Hakim Pengadilan Tinggi, sedang bagi MA tidak berlaku. Pada pengadilan tingkat pertama, evaluasi terhadap kinerja dan hasil pengawasan dilakukan oleh masing-masing pimpinan unit kerja, yang dalam hal ini adalah Ketua Pengadilan setempat. Pada Tingkat MA, kewenangan pengawasan berada pada Ketua Mahkamah Agung. Pengawasan hakim oleh MA dapat dibagi menjadi 2 (dua), pengawasan hakim di lingkungan MA sendiri dan pengawasan hakim di peradilan tingkat pertama dan banding. Sebelum adanya Ketua Muda Bidang Pengawasan dan Pembinaan (TUADA WASBIN) tahun 2001, pengawasan dilakukan oleh organ pengawas yaitu KORWASSUS (Koordinator Pengawas Khusus). KORWASSUS dipimpin oleh seorang Ketua Muda MA yang mempunyai tugas mengkoordinir pelaksanaan pengawasan hakim di MA secara fungsional. ${ }^{28}$ Dari segi teknis pelaksanaanya.

${ }^{28}$ Keputusan Ketua MA No. KMA/032/SK/IX/1992 tentang Organisasi. Tata Kerja. serra Pembagian Tugas dan Tanggung Jawab KORWASSUS. 
KORWASSUS dibantu oleh Hakim Agung Pengawasan Khusus (HAWASSUS) yang dibagi menjadi tiga bidang yaitu, bidang peradilan, pembinaan, dan Penelitian dan Pengembangan (Litbang) /Diklat. Dalam menjalankan tugasnya, setiap HAWASSUS dibantu oleh seorang hakim tinggi yustisial. Mengenai pengawasan terhadap pengadilan tingkat pertama/banding, MA mempunyai badan atau organ pengawasan yang bernama KORWIL (Koordinator Wilayah). KORWIL ini dijabat oleh beberapa Ketua Muda MA yang berfungsi sebagai koordinator pengawas. Dalam teknis pelaksanaannya, MA kemudian membentuk Hakim Pengawas Daerah (HAWASDA) yang terdiri dari sejumlah hakim agung yang tugasnya membantu pelaksanaan kerja Koordinator Wilayah di tiap-tiap daerah tertentu. Dalam menjalankan tugasnya, HAWASDA dibantu oleh Hakim Tinggi Pengawas pada MA (HATTIWASMA). HATTIWASMA ini terdiri dari hakim tinggi yustisial yang diperbantukan di MA. HATTIWASMA ini daibagi menjadi beberapa bidang antara lain, bidang advokat/notaris, peradilan militer, peradilan agama, peradilan tata usaha negara dan peradilan umum. Semua hasil pengawasan KORWASSUS, HAWASSUS, KORWIL, HAWASDA, dan HATTIWASMA diserahkan serta didokumentasikan kepada direktur hukum dan peradilan MA untuk diolah, disimpan yang sifatnya rahasia dan digunakan untuk penilaian oleh pimpinan MA.

\section{Komisi Kehormatan Profesi Hakim}

Komisi Kehormatan Profesi Hakim merupakan komisi yang dibentuk sebagai quasi yudisial dalam rangka menegakkan dan melakukan pendisiplinan hakim. Komisi Kehormatan Profesi Hakim mempunyai tugas :

1. Memberikan pembinaan pada anggota untuk selalu menjunjung tinggi kode etik

2. Meneliti dan memeriksa laporan/pengaduan dari masyarakat atas tingkah laku dari para anggota IKAHI

3. Memberikan nasehat dan peringatan kepada anggota dalam hal anggota yang bersangkutan menunjukkan tanda-tanda pelanggaran Kode Etik

Komisi Kehormatan Profesi Hakim berwenang: 
1. Memanggil anggota untuk didengar keterangannya sehubungan dengan adanya pengaduan dan laporan

2. Memberikan rekomendasi atas hasil pemeriksaan terhadap anggota yang melanggar Kode Etik dan merekomendasikan untuk merehabilitasi anggota yang tidak terbukti bersalah

Mekanisme pemeriksaan yang dilakukan oleh Komisi Kehormatan Hakim adalah:

1. Pemeriksaan terhadap anggota yang dituduh melanggar Kode Etik dilakukan secara tertutup;

2. Pemeriksaan harus memberikan kesempatan seluas-luasnya kepada anggota yang diperiksa untuk melakukan pembelaan diri;

3. Pembelaan dapat dilakukan sendiri atau didampingi oleh seorang atau lebih dari anggota yang ditunjuk oleh yang bersangkutan atau yang ditunjuk organisasi;

4. Hasil pemeriksaan dituangkan dalam Berita Acara Pemeriksaan yang ditandatangani oleh semua anggota Komisi Kehormatan Profesi Hakim dan yang diperiksa.

\section{Sistem Pemeriksaan dan Pendisiplinan ${ }^{29}$ Hakim}

Jika berdasarkan hasil pengawasan Irjen Departemen melalui instrumen DP3 dan MA dengan instrumen EVA.1 dan WAS.1 diperoleh dugaan kuat telah terjadi pelanggaran perilaku oleh hakim, baik melanggar Undang-Undang maupun peraturan pemerintah, ${ }^{30}$ maka hakim tersebut akan diperiksa oleh Irjen Departemen atau MA. Jika berdasarkan pemeriksaan tersebut Irjen Departemen atau MA memperoleh bukti bahwa hakim tersebut melakukan pelanggaran perilaku, maka Menteri selaku pimpinan Departemen, baik atas inisiatif sendiri maupun berdasarkan persetujuan MA, akan menjatuhkan sanksi sebagaimana yang telah

20. Yang dimaksud dengan pendisiplinan disini adalah suatu rangkaian proses penindaklanjutan hasil pengawasan yang berupa proses "mengadili" hakim-hakim yang diduga melakukan penyimpangan perilaku dan atau menjatuhkan sanksi kepadanya jika dianggap bersalah.

${ }^{30}$ Ada beberapa peraturan perundang-undangan yang secara umum mengatur mengenai perilaku hakim yang tidak diperkenankan, yaitu UU No. 8 Tahun 2004 tentang perubahan atas UU No. 2 Tahun 1986 tentang Peradilan Umum dan PP No. 30 Tahun 1980 tentang Disiplin PNS. 
diatur dalam PP No. 30 Tahun 1980 tentang Peraturan Disiplin PNS.

Dengan melihat peraturan perundang-undangan yang mengatur mengenai pendisiplinan hakim terlihat bahwa pada dasarnya pihak yang paling memiliki kewenangan dalam melakukan pendisiplinan terhadap hakim adalah Menteri. Menteri dapat menjatuhkan sanksi ringan, sedang atau berat (kecuali pemberhentian hakim baik tetap maupun sementara) tanpa membutuhkan persetujuan dari pihak manapun. Akan tetapi, khusus untuk pemberhentian hakim, baik pemberhentian tetap maupun pemberhentian sementara, kewenangan untuk menjatuhkan sanksi terletak pada 4 (empat) pihak yaitu Presiden, Menteri Kehakiman, Ketua MA, dan Majelis Kehormatan Hakim. Pasal 16 jo Pasal 20 ayat (2) UU No. 2 Tahun 1986 menjelaskan bahwa Hakim diberhentikan oleh Presiden atas usul Menteri dan berdasarkan persetujuan Ketua MA dan usulan pemberhentian tersebut hanya dapat dilakukan setelah hakim yang diduga bersalah tersebut membela diri dalam Majelis Kehormatan Hakim. ${ }^{31}$ Mengenai pemberhentian terhadap Hakim Agung, diatur dalam UU No. 14 Tahun 1985 pasal 12 dimana terdapat suatu mekanisme tersendiri dalam pemberhentiannya. Pasal 12 menyatakan bahwa hakim agung diberhentikan oleh Presiden atas usul Ketua MA dan usulan pemberhentian tersebut hanya dapat dilakukan setelah hakim agung tersebut membela diri dalam Majelis Kehormatan Hakim Agung. Kedua ketentuan mengenai Majelis Kehormatan Hakim dan Majelis Kehormatan Hakim Agung diatas diatur lebih lanjut dalam Peraturan Pemerintah No. 26 Tahun 1991 tentang Tata Cara Pemberhentian Dengan Hormat, Pemberhentian Tidak Dengan Hormat, dan Pemberhentian Sementara Serta Hak-Hak Hakim Agung dan Hakim yang Dikenakan Pemberhentian. Untuk Majelis Kehormatan akim, diatur lebih lanjut dalan Surat Keputusan Bersama (SKB) antara Menteri Kehakiman dan Ketua MA No. KMA/041/SKB/XI/1992 tentang Pembentukan, Susunan dan Tata Kerja Majelis Kehormatan Hakim Dalam Lingkungan Umum dan Peradilan Tata Usaha Negara.

Mekanisme pengawasan serta pendisiplinan hakim pada sistem pengawasan dua atap ini tidak berjalan secara efektif dan

"Majelis Kehormatan Hakim adalah lembaga yang memilik kewenangan mengadili (menerima dan memeriksa pembelaan diri) hakim yang diduga melakukan penyimpangan dan memberikan hasil pemeriksaannya kepada Menteri dan Ketua MA. 
optimal. Jarang sekali ada hakim yang mendapat sanksi pemberhentian, meskipun banyak indikasi dugaan penyimpangan perilaku yang dilakukan oleh hakim dan pegawai pengadilan lainnya. ${ }^{32} \mathrm{Hal}$ ini terjadi karena lemahnya proses pendidiplinan baik oleh Menteri maupun MA. Kelemahan pendisiplinan oleh MA antara lain disebabkan oleh beberapa hal yaitu:

- adanya keengganan/kesulitan untuk bertindak tegas kepada sesama hakim karena Majelis Kehormatan Hakim dan Majelis Kehormatan Hakim Agung hanya terdiri dari kalangan Hakim;

- tidak ada transparansi dan akuntabilitas dari proses pemeriksaan oleh Majelis Kehormatan Hakim. Hal ini dapat dilihat dari ketentuan dalam SKB yang menjelaskan bahwa sistem pemeriksaan terhadap hakim yang diduga melanggar kode etik perilaku hakim bersifat tertutup;

○ tidak adanya pedoman dalam penjatuhan sanksi.

\section{Sistem Pengawasan Satu Atap}

Pada masa pengawasan dua atap, Mahkamah Agung hanya memiliki kewenangan untuk melakukan pengawasan dan pembinaan teknis yudisial terhadap badan peradilan di bawah MA. Sedangkan pembinaan organisasi, administratif dan finansial badan peradilan tersebut ada di bawah departemen teknis masingmasing, misalnya untuk Peradilan Umum dan Peradilan Tata Usaha Negara berada di bawah Departemen Kehakiman sedangkan pengadilan agama berada di bawah Departemen agama. Sistem tersebut dianggap menjadi salah satu penyebab ketidakmandirian pengadilan dalam menjalankan tugas dan fungsinya. ${ }^{33}$ Dengan lahirnya Undang-Undang Nomor 35 Tahun 1999 tentang perubahan atas UU No. 14 Tahun 1970 tentang pokok-pokok kekuasaan kehakiman, maka pengawasan melalui sistem dua atap diganti dengan pengawasan melalui sistem penyatuan atap. Pasal 11 UU No. 14 Tahun 1970 yang merupakan

${ }^{32}$ Menurut laporan Komisi Ombudsman Nasional (KON) tahun 2002, pengaduan masyarajat berkaitan dengan penyelewengan yang terjadi di lembaga peradilan menempati urutan pertama (45\%) dibandingkan dengan lembaga-lembaga lain. Antonius Sujata dan RM Surachman, "Ombudsman Indonesia di Tangah Ombudsman Internasional". (Jakarta: KON, 2002), hal. 221.

${ }^{33}$ Mahkamah Agung RI, "Cetak Biru Pembaruan Mahkamah Agung”, (Jakarta: Mahkamah Agung RI. 2003). hal. 52. 
dasar sistem dua atap telah diubah dimana badan-badan peradilan sebagaimana dimaksud dalam pasal 10 ayat $1,^{34}$ secara organisatoris, administratif, dan finansial berada di bawah Mahkamah Agung. Seperti yang telah dijelaskan diatas bahwa mekanisme pengawasan hakim pada sistem satu atap dilakukan oleh pejabat baru yaitu Tuada Wasbin. Selain itu, pada tahun 2002 telah dibentuk unit baru di MA yang bertugas untuk membantu Tuada Wasbin, yaitu Asisten Bidang Pengawasan dan Pembinaan $^{35}$ sehingga diharapkan Tuada Wasbin dapat bekerja secara fulltime untuk melakukan pengawasan.

\section{Mekanisme Pengawasan ${ }^{36}$} adalah:

Mekanisme pengawasan yang dilakukan secara umum

1. penelitian awal terhadap indikasi pelanggaran perilaku yang diperoleh dari semua kegiatan pengawasan yaitu:

- pengawasan melekat;

- pengawasan rutin;

- pemantauan pemberitaan media;

- penerimaan laopran masyarakat;

2. rapat penentuan tindak lanjut atas temuan kegiatan pengawasan. Pada rapat ini setiap Pengawas Fungsional memaparkan hasil penelitian awal, kesimpulan serta rekomendasi tindak lanjut terhadap dugaan pelanggaran perilaku pejabat pengadilan yang berasal dari kegiatan pengawasan. Berdasarkan hasil pembahasan, Tuada Wasbin dan kepala badan pengawasan menentukan:

- apakah akan ditindak lanjuti atau tidak;

- jenis pelanggaran;

Militer.

${ }^{34}$ Peradilan umum, Peradilan Tata Usaha Negara, Peradilan Agama, dan Peradilan

35 Berdasarkan hasil wawancara dengan Bpk. Ansyahrul, Asisten Bidang Pengawasan dan Pembinaan Mahkamah Agung RI (ASBIDWASBIN) pada hari rabu tanggal 21 Desember 2005, bahwa tugas dari ASBIDWASBIN ini adalah sebagai supporting unit atau unit pelaksana dari TUADA WASBIN sesuai dengan Keputusan Sek Jen No. 13 Tahun 2002 tentang Pembentukan ASBIDWASBIN.

36 Mahkamah Agung dan Lembaga Kajian dan Advokasi untuk Independensi Peradilan (LeIP), "Kajian Pengembangan Sistem. Mekanisme Serta Tata Kerja Pengawasan. Penilaian Kualitas dan Kinerja Hakim”, (Jakarta: Mahkamah Agung RI, 2005), hal. 18. 
- ancaman hukuman disiplin yang dapat dijatuhkan;

3. kegiatan dan prosedur pemeriksaan. Prosedur pemeriksaan terhadap terperiksa dapat dibedakan berdasarkan jenis ancaman hukuman apakah diancaman dengan hukuman disiplin ringan atau dengan hukuman disiplin sedang dan berat.

4. penentuan rekomendasi akhir hasil pemeriksaan, dan penjatuhan sanksi. Pada prinsipnya pejabat/petugas pengawasan hanya berwenang untuk memberikan rekomendasi, sedangkan penjatuhan sanksi hanya dapat dilakukan oleh atasan yang berwenang menghukum atau pejabat yang ditunjuk yang diberikan wewenang untuk menjatuhkan sanksi. Rekomendasi dari pejabat/petugas pengawasan mempunyai kekuatan mengikat, kecuali terdapat bukti lain yang lebih kuat yang dapat mengakibatkan terbantahnya hasil-hasil pemeriksaan.

\section{B. Sistem Pengawasan Eksternal oleh Komisi Yudisial}

Sebenarnya ide tentang perlunya suatu lembaga khusus untuk menjalankan fungsi-fungsi tertentu yang berhubungan dengan kekuasaan kehakiman bukanlah hal yang baru. Dalam pembahasan Rancangan Undang-Undang tentang Ketentuan-Ketentuan Pokok Kekuasaan Kehakiman sekitar tahun 1968, sempat diusulkan pembentukan lembaga yang diberi nama Majelis Pertimbangan Penelitian Hakim (MPPH). Majelis ini berfungsi memberikan pertimbangan dalam mengambil keputusan terakhir mengenai saransaran dan atau usul-usul yang berkenaan dengan pengangkatan, promosi, kepindahan, pemberhentian dan tindakan/hukuman jabatan para hakim, yang diajukan baik oleh MA maupun Menteri Kehakiman. Namun dalam perjuangannya, ide tersebut menemui kegagalan dan tidak berhasil dimasukkan dalam UU No.14 Tahun 1970 tentang Ketentuan-Ketentuan Pokok Kekuasaan Kehakiman. Ide tersebut muncul kembali dan menjadi wacana yang semakin kuat dan solid sejak adanya desakan penyatuan atap bagi hakim tahun 1998-an. Pada tahun 1998 Majelis Permusyawaratan Rakyat (MPR) mengeluarkan Ketetapan MPR RI No. X/MPR/1998 tentang Pokok-pokok Reformasi Pembangunan dalam Rangka Penyelamatan dan Normalisasi Kehidupan Nasional sebagai Haluan Negara. Dalam TAP MPR tersebut dinyatakan perlunya segera diwujudkannya pemisahan yang tegas antar fungsi-fungsi yudikatif dari eksekutif. Keberadaan TAP 
MPR ini tidak lepas dari perjuangan para praktisi hukum, akademisi dan terutama hakim sejak puluhan tahun lalu untuk mewujudkan independensi peradilan di Indonesia.

Namun ternyata masalahnya tidak sesederhana itu. Setelah adanya komitmen politik untuk memberlakukan penyatuan atap -pemindahan kewenangan administrasi, personel, keuangan dan organisasi pengadilan dari departemen ke Mahkamah Agung (MA)- muncul kekhawatiran baru: lahirnya monopoli kekuasaan kehakiman oleh MA. Selain itu MA dianggap belum mampu menjalankan seluruh tugas dan wewenangnya tersebut secara maksimal. Namun kelemahan ini sedikit banyak juga berhubungan dengan masih adanya sistem dua atap. Menyadari masalah di atas, Tim Kerja Terpadu Mengenai Pengkajian Pelaksanaan TAP MPR No. X/MPR/1998 berkaitan dengan Pemisahan yang Tegas antara Fungsi-fungsi Yudikatif dan Eksekutif (Tim Kerja Terpadu) menyimpulkan bahwa penyatuan atap --tanpa perombakan sistem tertentu-- berpotensi untuk melahirkan monopoli kekuasaan kehakiman. Oleh sebab itu, Tim Kerja Terpadu tersebut --yang diketua oleh Ketua Muda MA dan beranggotakan unsur hakim, akademisi, advokat dan pemerintah-- memberikan rekomendasi perlunya penyatuan atap di satu sisi dan perlunya pembentukan Dewan Kehormatan Hakim yang berwenang mengawasi perilaku hakim, memberikan rekomendasi mengenai rekrutmen, promosi dan mutasi hakim serta menyusun code of conduct bagi hakim di sisi lain. Dalam batas-batas tertentu, International Commission of Jurist memberikan rekomendasi yang hampir sama.

Rekomendasi Tim Kerja Terpadu kemudian diadopsi dalam UU No. 35 Tahun 1999 tentang Perubahan atas Undang-Undang No.14 Tahun 1970 tentang Ketentuan-Ketentuan Pokok Kekuasaan Kehakiman (UU No. 35/1999). Pasal I angka 1 dan angka 2 UU No. 35/1999 menyebutkan bahwa kewenangan pembinaan administrasi, organisasi dan finansial hakim diserahkan ke MA. Penyerahkan ini harus dilakukan dalam waktu paling lambat 5 tahun (sampai dengan tahun 2004). Selain itu, dalam penjelasan umum UU tersebut menegaskan bahwa perlu dibentuk Dewan Kehormatan Hakim yang berwenang mengawasi perilaku hakim, memberikan rekomendasi mengenai rekrutmen, promosi dan mutasi hakim serta menyusun code of conduct bagi hakim. Pentingnya keberadaan Dewan Kehormatan Hakim ditegaskan dan diperjelas kembali dalam UU No.25 tahun 2000 tentang Program Pembangunan Nasional (PROPENAS) dan RUU Mahkamah Agung versi Pemerintah. Perbedaaan antara PROPENAS dan RUU MA tersebut dengan UU No. 35/1999 adalah 
dalam penggunaan istilah. Jika UU No. 35/1999 menggunakan istilah "Dewan Kehormatan Hakim", PROPENAS dan RUU MA versi pemerintah menggunakan istilah "Komisi Yudisial". Selain itu, PROPENAS mengamanatkan agar fungsi Komisi Yudisial lebih fokus di bidang pengawasan. Sedang RUU MA menekankan pada aspek pengawasan dan pemberian rekomendasi serta pertimbangan kebijakan peradilan kepada pimpinan MA (dalam aspek non teknis yudisial).

Pada Sidang Tahunan MPR tahun 2001 yang membahas mengenai amandemen ketiga Undang-Undang Dasar 1945 (UUD 1945), telah disepakati beberapa perubahan dan penambahan pasal yang berkenaan dengan kekuasaan kehakiman, termasuk di dalamnya Komisi Yudisial. Lahirlah Pasal 24B yang menyatakan perlunya dibentuk Komisi Yudisial yang bersifat mandiri yang berwenang mengusulkan pengangkatan Hakim Agung dan mempunyai wewenang lain dalam rangka menjaga dan menegakkan kehormatan, keluhuran martabat, serta perilaku hakim (ayat 1). Se1ain itu dalam ayat 2, 3 dan 4 diatur secara umum mengenai persyaratan anggota Komisi Yudisial, mekanisme pengangkatannya serta perlunya pengaturan rinci hal-hal lain dalam $\mathrm{UU}^{37}$. Dalam Draf RUU tentang Komisi Yudisial (Sekarang telah menjadi Undang-Undang Nomor 22 Tahun 2004 tentang Komisi Yudisial), ternyata Komisi Yudisial tersebut hanya bertugas melakukan seleksi calon Hakim Agung, dan pengawasan terhadap prilaku hakim ${ }^{38}$. Berarti tugas-tugas lain, seperti: rekrutmen hakim, penempatan, pembinaan/pelatihan (training), managemen administrasi dan perbaikan nasib (penghasilan) hakim, masih tetap seperti biasa, yaitu berada di Mahkamah Agung ${ }^{39}$. Tugas pengawasan dan

${ }^{37}$ Mahkamah Agung RI, 2003 Op. Cit., hal. 12-15. Ketujuh alinea tersebut langsung dikutif dalam tulisan ini, karena dianggap relevan untuk menguraikan tugas Komisi Yudisial dalam RUU yang diajukan.

${ }^{38}$ Lihat, Pasal 5 Draf RUU tersebut. Disana dikatakan: "Komisi mempunyai fungsi: (a). Mengusulkan pengangkatan Hakim Agung. (b). Menjaga dan menegakkan kehormatan, keluhuran martabat, serta perilaku hakim. Pasal-pasal berikutnya dari draf RUU tersebut, hanya menjabarkan kedua tugas tersebut dengan lebih detail lagi. Draf tersebut telah diambil over ke dalam undang -undang, dan hampir tidak ada perubahan ) Lihat: Pasal 13 dst dari UU tersebut (Indonesia. Undang-Undang Tentang Komisi Yudisial, Undang-Undang No. 22 tahun 2004, LN No. 89 tahun 2004: TLN. 4415.

39 Dahulu sebelum satu atap, hal tersebut banyak ditangani oleh Departemen Kehakiman RI, yang dalam banyak hal sering tidak terjadi keharmonisan dengan Mahkamah Agung. Seperti dalam hal mutasi, promosi, dan pelatihan (training). Sering-sering Mahkamah Agung RI mengklaim bahwa sebagai pemakai (user), lebih berkompeten menentukan akan hal itu, dan demikian sebaliknya dari pihak Departemen. 
pembinaan masih tetap dipegang oleh Mahkamah Agung RI, bahkan akhir-akhir ini dibentuk satu bagian yang disebut Ketua Muda Bidang Pengawasan yang dikepalai oleh salah seorang Hakim Agung dan bertanggungjawab menangani hal-hal tentang pengawasan dan pembinaan tersebut ${ }^{40}$. Berbeda dengan Komisi Yudisial di banyak negara, bahwa hal itu bukan lagi wewenang dari Mahkamah Agung RI, akan tetapi ditangani oleh suatu lembaga yang independen. Minimnya bidang tugas dari Komisi Yudisial yang akan datang, barangkali oleh karena baru pertama kali ini Komisi Yudisial dibentuk. Nanti, dalam perjalanan waktu akan berkembang sendiri seperti di negara-negara lain tersebut.

Pada tahun 2004 telah disahkan Undang-Undang Nomor 22 Tahun 2004 tentang Komisi Yudisial dimana dalam pasal 13 disebutkan bahwa salah satu kewenangannya adalah menegakkan kehormatan dan keluhuran martabat serta menjaga perilaku hakim. ${ }^{41}$ Dengan adanya Undang-Undang ini, Komisi Yudisial secara hukum merupakan suatu lembaga pengawasan eksternal bagi profesi hakim yang diatur dalam konstitusi Negara Republik Indonesia yaitu UUD 1945.

\section{Mekanisme Pengawasan oleh Komisi Yudisial}

Berdasarkan pasal 22 UU No. 22 Tahun 2004, dalam melaksanakan pengawasannya, Komisi Yudisial:

a. Menerima laporan masyarakat tentang perilaku hakim;

b. Meminta laporan secara berkala kepada badan peradilan berkaitan dengan perilaku hakim;

${ }^{40}$ Indonesia (C), OP. Cit. Pasal 32 berbunyi sebagai berikut: (1) Mahkamah Agung melakukan pengawasan tertinggi terhadap penyelenggaraan peradilan di semua lingkungan peradilan dalam menjalankan Kekuasaan Kehakiman; (2) Mahkamah Agung mengawasi tingkah laku dan perbuatan para hakim di semua lingkungan peradilan dalam menjalankan tugasnya: (3) Mahkamah Agung berwenang untuk meminta keterangan tentang hal-hal yang bersangkutan dengan teknis peradilan di semua lingkungan peradilan; (4) Mahkamah Agung berwenang memberi petunjuk, teguran, atau peringatan yang dipandang perlu kepada pengadilan di semua lingkungan pengadilan; (5) Pengawasan dan kewenangan sebagaimana dimaksudkan dalam ayat (1) sampai dengan ayat (4) tidak boleh mengurangi kebebasan hakim dalam memeriksa dan memutus perkara.

${ }^{41}$ Indonesia (E). Undang-Undang tentang Komisi Yudisial, UU Nomor 22 Tahun 2004. LN Tahun 2004 Nomor 89. Pasal 13 bahwa Komisi Yudisial mempunyai wewenang yaitu mengusulkan pengangkatan Hakim Agung kepada DPR dan menegakkan kehormatan dan keluhuran serta menjaga perilaku hakim. 
c. Melakukan pemeriksaan terhadap dugaan pelanggaran perilaku hakim;

d. Memanggil dan meminta keterangan dari hakim yang diduga melanggar kode etik perilaku hakim;

e. Membuat laporan hasil pemeriksaan berupa rekomendasi dan disampaikan kepada Mahkamah Agung dan/atau Mahkamah Konstitusi, serta tindasannya disampaikan kepada Presiden dan DPR;

Laporan hasil pemeriksaan yang berupa rekomendasi juga berisi tentang usul penjatuhan sanksi, dimana usul penjatuhan sanksi terhadap hakim dapat berupa: ${ }^{42}$
a. teguran tertulis;
b. pemberhentian sementara;
c. pemberhentian;

Berdasarkan usul penjatuhan sanksi yang diberikan oleh Komisi Yudisial, terdapat perbedaan mengenai sifat dari ke-3 usul penjatuhan sanksi tersebut. Mengenai usul penjatuhan sanksi berupa teguran tertulis beserta alasan kesalahannya bersifat mengikat, disampaikan oleh Komisi Yudisial kepada pimpinan Mahkamah Agung dan/atau Mahkamah Konstitusi. ${ }^{43}$ Terdapat keanehan dalam isi pasal ini dimana pada pasal 22 angka (1) huruf e dinyatakan bahwa laporan hasil pemeriksaan merupakan rekomendasi dan pasal 21 secara jelas menyatakan bahwa Komisi Yudisial bertugas mengajukan usul penjatuhan sanksi. Hal ini menandakan tidak konsistennya tugas Komisi Yudisial yang diatur dalam UU No. 22 Tahun 2004 karena usul penjatuhan sanksi berupa teguran tertulis sifatnya adalah mengikat. Kemudian mengenai usul penjatuhan sanksi berupa pemberhentian sementara dan pemberhentian diatur dalam pasal 23 angka (3) sampai angka (6) UU No. 22 Tahun 2004. pada angka (3) pasal tersebut dijelaskan bahwa usul penjatuhan sanksi berupa pemberhentian sementara dan pemberhentian diserahkan oleh Komisi Yudisial kepada Mahkamah Agung dan/atau Mahkamah Konstitusi. Letak perbedaan antara usul penjatuhan sanksi berupa teguran tertulis dengan pemberhentian sementara dan pemberhentian yaitu dalam usul penjatuhan sanksi berupa

\footnotetext{
${ }^{42}$ Ibid., Pasal 23 angka 1.

${ }^{43} \mathrm{Ibid}$., pasal 23 angka 2.
} 
teguran tertulis, Komisi Yudisial menyampaikannya kepada pimpinan Mahkamah Agung, sedangkan pada usul penjatuhan sanksi berupa pemberhentian sementara dan pemberhentian, Komisi Yudisial menyerahkan usulan tersebut kepada pimpinan Mahkamah Agung.

Pada mekanisme usul penjatuhan sanksi berupa pemberhentian sementara dan pemberhentian, setelah usul penjatuhan sanksi berada pada pimpinan Mahkamah Agung, hakim yang akan dijatuhi sanksi diberi kesempatan secukupnya untuk membela diri di hadapan Majelis Kehormatan Hakim. ${ }^{44}$ Hal ini telah dijelaskan pada $\mathrm{BAB}$ sebelumnya mengenai pengawasan hakim oleh Mahkamah Agung yaitu mengenai sanksi pelanggaran disiplin berupa pemberhentian sementara dan pemberhentian, hakim yang akan dijatuhi sanksi memiliki hak untuk membela diri di depan Majelis Kehormatan Hakim. Hal ini diatur dalam UU No. 8 Tahun 2004 tentang Peradilan Umum pasal 20 angka 2, UU No. 9 Tahun 2004 tentang Peradilan Tata Usaha Negara pasal 20 angka 2. dalam hal pembelaan diri ditolak, usul pemberhentian hakim diajukan oleh Mahkamah Agung kepada Presiden paling lambat 14 (empat belas) hari sejak pembelaan diri ditolak oleh Majelis Kehormatan Hakim ${ }^{45}$ dan Keputusan Presiden mengenai pemberhentian hakim, ditetapkan dalam jangka waktu paling lama 14 (empat belas) hari sejak Presiden menerima usul Mahkamah Agung. ${ }^{46}$ Saat ini, Komisi Yudisial telah memiliki perangkat untuk memudahkan dalam melaksanakan tugasnya mengawasai perilaku hakim dengan adanya Peraturan komisi Yudisial Nomor 1 Tahun 2006 tentang Tata Cara Pengawasan Hakim. Dengan adanya peraturan tersebut akan semakin memperjelas kemana arah Komisi Yudisial dalam menjalankan kewenangannya untuk menegakkan kehormatan dan keluhuran martabat serta menjaga perilaku hakim.

\footnotetext{
${ }^{44}$ Ibid., Pasal 23 angka 4.

${ }^{45}$ Ibid., Pasal 23 angka 5.

${ }^{46}$ Ibid., Pasal 23 angka 6.
} 
IV. Analisa Yurisdiksi Pengawasan Eksternal dan Internal Hakim Dalam Kasus Pemeriksaan Hakim PT Bandung Terkait Perkara Pemilihan Kepala Daerah Kota Depok

\section{A. Pemeriksaan Hakim oleh Komisi Yudisial}

Pengawasan, baik pengawasan internal maupun pengawasan eksternal dilakukan dengan maksud untuk mengawasi jalannya penegakan hukum di Indonesia. Menurut Wayne La Fahre penegakan hukum sebagai suatu proses pada hakikatnya merupakan penerapan diskresi yang menyangkut membuat keputusan yang tidak secara ketat diatur oleh kaidah hukum, tetapi mempunyai unsur penilaian pribadi. ${ }^{47}$ Dengan mengutip pendapat Roscoe Pound, maka La Favre menyatakan bahwa pada hakikatnya diskresi berada diantara hukum dan moral (etika dalam arti sempit). ${ }^{48}$ Oleh karena itu, dapatlah dikatakan bahwa penegakan hukum bukanlah semata-mata berarti pelaksanaan perundang-undangan, karena ada kecenderungan yang kuat untuk mengartikan penegakan hukum sebagai pelaksanaan keputusan hakim. Dengan demikian, penegakan hukum akan terganggu jika keputusan-keputusan yang dikeluarkan oleh hakim tidak mencerminkan kepastian hukum dan keadilan dalam kehidupan masyarakat.

Salah satu upaya mencegah terganggunya atau bahkan terpuruknya penegakan hukum di Indonesia, adalah dengan memperketat mekanisme pengawasan terhadap hakim terutama terhadap putusan yang dikeluarkannya. Kewenangan pengawasan terhadap perilaku hakim, selain yang dimiliki oleh Mahkamah Agung, juga dimiliki oleh Komisi Yudisial. Hal ini sesuai dengan konsep teori pengawasan, dimana salah satu konsep pengawasan adalah pengawasan intern dan ekstern. Mahkamah Agung sebagai lingkup peradilan tertinggi di Indonesia bertindak sebagai lembaga pengawasan internal sedangkan Komisi Yudisial sebagai Lembaga Negara yang baru dibentuk dengan Undang-Undang berperan sebagai lembaga pengawasan eksternal terhadap perilaku hakim. Oleh karena itu, sering terjadi tumpang tindih pelaksanaan pengawasan terhadap

${ }^{47}$ Soerjono Soekanto, "Faktor-Faktor yang Mempengaruhi Penegakan Hukum", Cet.5, (Jakarta: PT Raja Grafindo Persada, 2005), hal. 7.

${ }^{48} \mathrm{Ibid}$. 
perilaku hakim. Sementara Komisi Yudisial juga memiliki dasar hukum yang kuat karena diatur dalam Undang-Undang Dasar 1945.

Salah satu kasus menarik yang dapat dijadikan suatu tinjauan untuk membahas sejauh mana yurisdiksi kewenangan antara Mahkamah Agung dan Komisi Yudisial adalah mengenai Pemeriksaan Hakim Pengadilan Tinggi (PT) Bandung terkait dengan Kasus Sengketa Pemilihan Kepala Daerah Kota Depok. Berdasarkan pengaduan yang disampaikan oleh Tim sukses calon walikota Depok, Nurmahmudi Ismail kepada Komisi Yudisial, Komisi Yudisial kemudian melakukan pemeriksaan terhadap Majelis Hakim PT Bandung. Dasar wewenang Komisi Yudisial melakukan pemeriksaan terhadap Majelis Hakim tersebut adalah pasal 13 huruf (b) jo pasal 20 UU Nomor 22 Tahun 2004 tentang Komisi Yudisial dimana Komisi Yudisial berwenang menegakkan kehormatan dan keluhuran martabat serta menjaga perilaku hakim dan dalam melaksanakan wewenangnya tersebut Komisi Yudisial mempunyai tugas melakukan pengawasan terhadap perilaku hakim. Setelah menerima laporan dari calon Walikota Depok Nurmahmudi Ismail, kemudian ditetapkan Tim untuk membahas apakah laporan pengaduan tersebut dapat ditindaklanjuti atau tidak.

Dasar sebuah laporan pengaduan dapat ditindaklanjuti atau tidak dilihat dari laporan pengaduan yang diterima apakah telah memenuhi syarat formal pengaduan dan apakah laporan pengaduan tersebut berada dalam kewenangan Komisi Yudisial atau tidak. Adapun syarat formal laporan pengaduan terdapat pada pasal 2 angka (1) Peraturan Komisi Yudisial Nomor 1 Tahun 2006 tentang tata cara pengawasan hakim yaitu memuat:

a. Identitas pelapor dan terlapor yang lengkap;

b. Uraian mengenai hal yang menjadi dasar laporan yang meliputi alasan laporan yang diuraikan secara jelas dan rinci beserta alat bukti yang diperlukan serta hal-hal yang dimohonkan untuk diperiksa dalam laporan dimaksud;

c. Laporan pengaduan ditandatangani oleh pelapor atau kuasanya;

Mengenai laporan pengaduan yang diajukan ke Komisi Yudisial, harus diperiksa apakah pengaduan tersebut sudah tepat merupakan kewenangan Komisi Yudisial berdasarkan pasal 13 huruf (b) UU Nomor 22 Tahun 2004 tentang Komisi Yudisial. Apabila syarat tersebut telah terpenuhi, maka pengaduan disampaikan kepada pimpinan oleh Sekretariat Jenderal. Setelah dinyatakan dapat diperiksa, kemudian Tim menetapkan hari pemeriksaan kepada 
pelapor dan atau terlapor. Pemeriksaan dilakukan oleh Tim secara tertutup untuk umum. Adapun pemeriksaan yang dilakukan dapat berupa:

a. pemeriksaan laporan pengaduan atau informasi mengenai dugaan pelanggaran kehormatan, keluhuran martabat, serta perilaku hakim;

b. Pemeriksaan alat bukti tertulis, antara lain putusan hakim;

c. Mendengarkan keterangan pelapor atau terlapor;

d. Mendengarkan keterangan saksi;

e. Mendengarkan keterangan ahli;

f. Pemeriksaan rangkaian data, keterangan, perbuatan, keadaan, dan/atau peristiwa yang bersesuaian dengan alat-alat bukti lain yang dapat dijadikan petunjuk, termasuk dalam hal ini proses dalam pengambilan putusan hakim;

g. Pemeriksaan alat-alat bukti lain yang berupa informasi yang diucapkan, dikirimkan, diterima, atau disimpan secara elektronik dengan alat optik atau yang serupa dengan itu;

Pemeriksaan yang dilakukan oleh Tim terkait dengan pemeriksaan Majelis Hakim PT. Bandung adalah pemeriksaan putusan hakim dan mendengarkan keterangan terlapor. ${ }^{49}$ Satu hakim diperiksa oleh satu anggota Komisi Yudisial. Nana Juwana, Ketua PT Jabar yang juga Ketua Majelis sengketa Pilkada Depok diperiksa oleh Irawady Joenoes. Hakim anggota Hadi Lelana diperiksa M. Thahir Saimima. Selanjutnya, Rata Kembaren diperiksa oleh Zaenal Arifin. Sementara Sopyan Royan diperiksa oleh M. Busyro Muqoddas. Dan terakhir, Ginalita Silitonga, diperiksa oleh Soekotjo Soeparto. Sedangkan dua anggota KY sisanya, Chatamarasyid dan Mustofa Abdulah membantu jalannya pemeriksaan. Adapun pada pemeriksaan terlapor ini ditemui beberapa kendala. selama pemeriksaan kelima hakim PT Bandung tersebut, Nana Juwana bersikap tidak kooperatif dengan tidak menjawab beberapa pertanyaan tertentu dari Komisi Yudisial dengan alasan diperintahkan oleh Mahkamah Agung untuk tidak menjawab hal-hal yang menyangkut materi putusan. Namun ada juga hakim yang berterus-terang dan bersikap kooperatif.

Mengenai pemeriksaan alat bukti tertulis, yaitu putusan majelis PT Bandung, telah diuraikan diatas terdapat beberapa kejanggalan. Menurut Komisi Yudisial, Majelis Hakim PT Bandung yang

49 Berdasarkan wawancara dengan salah satu anggota Komisi Yudisial, Bapak Irawady Joenoes pada Hari Kamis, 9 Maret 2006. 
memeriksa dan mengadili perkara sengketa Pilkada Depok terbukti melakukan kesalahan dan kekeliruan berupa 'unprofessional conduct' secara formil dan materiil". Kesalahan formil yang dilakukan oleh lima anggota Majelis Hakim itu, ialah melanggar Pasal 106 Ayat 4 UU 32 Tahun 2004 tentang Pemerintahan Daerah bahwa perkara sengketa Pilkada harus diputus paling lambat dalam jangka waktu 14 hari. Perkara tersebut diterima oleh PT Bandung pada 12 Juli 2005, namun baru diputuskan pada 4 Agustus 2005, sehingga meski jumlah hari kerja tidak diperhitungkan proses keputusan perkara itu telah melewati batas waktu yang telah ditentukan. Demikian pula dengan batas waktu pengajuan permohonan perkara, yang menurut Komisi Yudisial, melewati batas waktu tiga hari karena perkara tersebut didaftarkan melalui Pengadilan Negeri Cibinong pada 11 Juli 2005 sedangkan penetapan hasil penghitungan suara Pilkada Depok dilakukan oleh KPUD Depok pada 6 Juli 2005. Kesalahan materil yang dilakukan oleh kelima hakim PT Bandung itu, menurut hasil pemeriksaan Komisi Yudisial, ialah dilampauinya batas wewenang dalam mengadili serta mempertimbangkan hal-hal yang berada di luar obyek sengketa hasil Pilkada. Seharusnya yang menjadi wewenang PT hanya yang berkenaan dengan hasil penghitungan suara yang mempengaruhi terpilihnya pasangan calon saja. Namun pemeriksaan juga menyangkut penggembosan atau penggelembungan suara dan adanya pemilih fiktif yang sebenarnya merupakan wewenang Panitia Pengawas Pilkada. Kelima anggota Majelis Hakim itu juga dinilai melanggar asas imparsialitas, atau ketidakberpihakan, dalam proses pengambilan keputusan karena tidak mempertimbangkan bukti-bukti dari termohon, yaitu KPUD Depok, berupa bukti rekapitulasi penghitungan suara. Majelis Hakim PT Bandung juga dinilai menggunakan asumsi dalam pertimbangan hukum mereka dengan menerima saja bukti-bukti yang diajukan pemohon, yakni pihak Badrul Kamal dan Syihabuddin Ahmad, tanpa melakukan pengabsahan dan disertainya bukti-bukti otentik.

Setelah pemeriksaan selesai, kemudian dilakukan rapat pleno secara tertutup dan bersifat rahasia yang dipimpin oleh Ketua Komisi Yudisial. Tujuan rapat pleno ini guna mengambil putusan sanksi kepada terlapor yang akan direkomendasikan kepada Mahkamah Agung. Berdasarkan pasal 23 angka (1) UU No. 22 Tahun 2004 tentang Komisi Yudisial, usul penjatuhan sanksi terhadap hakim dapat berupa: 
a. teguran tertulis;
b. pemberhentian sementara;
c. pemberhentian;

Dalam rapat pleno terhadap hasil pemeriksaan Majelis Hakim PT Bandung, kesimpulannya bahwa berdasarkan hasil pemeriksaan Majelis yang menangani sengketa pilkada Walikota Depok terbukti melakukan pelanggaran dalam proses pengambilan putusan. Pelanggaran yang dilakukan majelis adalah pelanggaran terhadap kode etik hakim, hukum acara dan prinsip-prinsip keadilan. Majelis PT Bandung yang memutus sengketa Pilkada Walikota Depok terdiri dari: Nana Juwana, Sopyan Royan, Rata Kembaren, Ginalita Silitonga, Hadi Lelana. Komisi Yudisial merekomendasikan kepada Mahkamah Agung agar memberhentikan sementara Ketua Majelis Nana Juwana selama satu tahun. Sementara, untuk empat anggota majelis lainnya, Komisi Yudisial merekomendasikan sanksi teguran tertulis. Sehubungan dengan perbedaan rekomendasi sanksi antara ketua majelis dan anggotanya, Ketua Komisi Yudisial Busyro Muqoddas menjelaskan bahwa Nana Juwana diberikan sanksi yang lebih berat dengan pertimbangan kedudukannya sebagai ketua majelis sekaligus ketua PT Jabar. ${ }^{50}$ Selaku Ketua Majelis sekaligus Ketua Pengadilan, Nana Juwana seharusnya memberi teladan yang baik. Usul penjatuhan sanksi teguran tertulis terhadap anggota Majelis Hakim PT Bandung bersifat mengikat disampaikan oleh Komisi Yudisial kepada pimpinan Mahkamah Agung sesuai dengan bunyi pasal 23 angka (2) UU No. 22 Tahun 2004 tentang Komisi Yudisial. Setelah pemeriksaan selesai, laporan hasil pemeriksaan tersebut diteruskan kepada Ketua Mahkamah Agung untuk ditindak lanjuti.

Berdasarkan pertimbangan Mahkamah Agung, rekomendasi Komisi Yudisial yang diterima akan dipertimbangkan secara hati-hati. Pertama, rekomendasi tersebut tidak melebihi kewenangan dari Komisi Yudisial dan juga rekomendasi tidak mengganggu tatanan peradilan yang ada, misalnya menyangkut kebebasan hakim. Oleh karena ketika rekomendasi Komisi Yudisial keluar ketika perkara sengketa Pilkada Depok belum selesai, Mahkamah Agung akan menampung dulu rekomendasi tersebut dan menunggu sampai putusan sengketa tersebut sudah final dan mengikat. Alasannya, bahwa dikhawatirkan akan mempengaruhi pemeriksaan atas pokok perkara

so Berdasarkan wawancara tertulis dengan Ketua Komisi Yudisial, M. Busyro Muqoddas pada Hari Senin, 13 Maret 2006 di Komisi Yudisial. 
dari sengketa tersebut. pada kenyataannya, atas putusan PT Bandung mengenai sengketa Pilkada Depok diajukan Peninjauan Kembali ke Mahkamah Agung sehingga rekomendasi tersebut dapat ditindaklanjuti setelah keluar putusan Peninjauan Kembali dari Mahkamah Agung.

\section{B. Pemeriksaan Hakim oleh Mahkamah Agung}

Mekanisme pengawasan oleh Mahkamah Agung dipegang oleh Ketua Muda Bidang Pengawasan dan Pembinaan (TUADAWASBIN). Khusus mengenai mekanisme pemeriksaan terhadap hakim yang diduga melanggar kode etik pemeriksaan hakim, adalah kewenangan dari Ketua Muda Bidang Pengawasan Mahkamah Agung yang dibantu oleh Asisten Bidang Pengawasan dan Pembinaan (ASBIDWASBIN).

Akan tetapi terdapat kesulitan dalam menentukan proses pemeriksaan yang dilakukan oleh Mahkamah Agung terhadap hakim yang diduga melanggar kode etik perilaku hakim sebab perangkat peraturan yang digunakan untuk melakukan pengawasan maupun evaluasi terhadap hakim belum disesuaikan dengan isi dari UndangUndang Nomor 4 Tahun 2004 tentang Kekuasaan Kehakiman, Undang-Undang Nomor 5 Tahun 2004 tentang Mahkamah Agung, Undang-Undang Nomor 8 Tahun 2004 tentang Perubahan Atas UU No. 2 Tahun 1986 tentang Peradilan Umum, dan Undang-Undang Nomor 9 Tahun 2004 tentang Perubahan Atas UU No. 5 Tahun 1986 tentang Peradilan Tata Usaha Negara. Dalam UU tersebut secara tertulis telah mengubah sistem pengadilan di Indonesia dari sistem pengadilan dua atap menjadi sistem pengadilan satu atap. Dengan diberlakukannya UU tersebut, pembinaan teknis peradilan, organisasi, administrasi, dan finansial pengadilan yang dulunya dilakukan oleh Departemen Kehakiman telah digantikan oleh Mahkamah Agung. Disamping itu, terjadi perubahan status hakim dari PNS menjadi pejabat negara.

Adapun peraturan yang menyangkut pengawasan dan pendisiplinan hakim adalah:

a. Peraturan Pemerintah Nomor 30 Tahun 1980 tentang Disiplin PNS;

b. Peraturan Pemerintah Nomor 26 Tahun 1991 tentang Tata Cara Pemberhentian dengan Hormat, Pemberhentian Tidak dengan Hormat, dan Pemberhentian Sementara serta Hak-Hak Hakim Agung dan Hakim yang Dikenakan Pemberhentian; 
c. SKB Ketua MA dan Menteri Kehakiman No. 41/SKB/XI/1992No. M.05-PW-07.10.1992 tentang Majelis Kehormatan Hakim;

Selama belum dikeluarkannya peraturan yang menyesuaikan sistem peradilan satu atap ini, seluruh peraturan yang lama masih dapat digunakan dengan mengkontekstualkan peraturan tersebut dengan perubahan status hakim dan sistem saru atap. Kata-kata dalam peraturan tersebut yang masih menggunakan kata "PNS" harus diganti "Pejabat Negara" dan kata "Departemen", "Menteri", "Direktur Jenderal atau Inspektorat Jenderal" harus dibaca "MA", "Ketua MA" dan "Pejabat MA yang ditunjuk" dan sebagainya. Terkait dengan kasus pemeriksaan Hakim Pengadilan Tinggi Bandung yang memeriksa perkara sengketa Pilkada Depok, berdasarkan rekomendasi dari Komisi Yudisial agar memberhentikan sementara Ketua Majelis Nana Juwana selama satu tahun dan untuk empat anggota majelis lainnya, Komisi Yudisial merekomendasikan sanksi teguran tertulis. Telah dikemukakan bahwa yang menjadi perhatian dari Mahkamah Agung adalah mengenai pemberhentian sementara dari Ketua Majelis yaitu Nana Juwana yang juga Ketua Pengadilan Tinggi Bandung. Mekanisme pemberian sanksi pemberhentian memiliki aturan yang khusus dibanding dengan sanksi lain. Hal ini diatur dalam pasal 22 UU No. 8 Tahun 2004 tentang perubahan atas UU No. 2 Tahun 1986 tentang Peradilan Umum serta Peraturan Pemerintah Nomor 26 Tahun 1991 tentang Tata Cara Pemberhentian dengan Hormat, Pemberhentian Tidak dengan Hormat, dan Pemberhentian Sementara serta Hak-Hak Hakim Agung dan Hakim yang Dikenakan Pemberhentian. Sesuai dengan PP No. 26 Tahun 1991 tersebut, hakim yang akan dijatuhi sanksi pemberhentian sementara memiliki hak untuk melakukan pembelaan diri di depan Majelis Kehormatan Hakim. Mengenai tata cara pemeriksaan hakim yang dilakukan oleh Majelis Kehormatan Hakim, diatur dalam SKB Ketua MA dan Menteri Kehakiman No. 41/SKB/XI/1992-No. M.05-PW-07.10.1992 tentang Majelis Kehormatan Hakim. Dalam SKB tersebut disebutkan bahwa:

a. Majelis Kehormatan Hakim berkedudukan di Pengadilan tinggi yang menjadi wilayah hukum dari hakim yang diduga melakukan pelanggaran;

b. Majelis Kehormatan Hakim dibentuk dalam waktu 30 hari setelah diterima pemberitahuan dari pihak yang berkepentingan atau telah ada sangkaan kuat;

c. Majelis Kehormatan Hakim dibentuk untuk jangka waktu 3 Tahun; 
Mengenai mekanisme pemeriksaannya, dalam SKB tersebut disebutkan bahwa:

1. hakim yang diperiksa dapat melakukan pembelaan diri yang secukupnya dalam jangka waktu 1 (satu) minggu setelah hasil pemeriksaan diberitahukan;

2. pemeriksaan yang dilakukan oleh Majelis Kehormatan Hakim bersifat tertutup;

3. pemeriksaan dilakukan dalam jangka waktu 2 (dua) minggu dan dapat diperpanjang untuk 2 (dua) minggu berikutnya;

4. hasil pemeriksaan direkomendasikan kepada Ketua MA dan Menteri Kehakiman;

5. Berita acara Pemeriksaan dikirimkan kepada Ketua Mahkamah Agung;

Setelah melakukan pemeriksaan, Majelis Kehormatan Hakim kemudian memberikan pertimbangan, pendapat dan saran kepada Ketua Mahkamah Agung mengenai hasil pemeriksaannya. Pertimbangan, pendapat, dan saran tersebut disampaikan dalam tenggang waktu 30 (tiga puluh) hari setelah diterimanya pembelaan diri hakim yang bersangkutan. Dalam hal diperlukan keteranganketerangan atau penjelasan tambahan maka tenggang waktu tersebut dapat diperpanjang untuk selama-lamanya 30 (tiga puluh) hari. Apabila berdasarkan pemeriksaan Majelis Kehormatan Hakim, Hakim Nana Juwana terbukti telah melakukan pelanggaran kode etik perilaku hakim sesuai dengan rekomendasi dari Komisi Yudisial, Ketua Mahkamah Agung kemudian menjatuhkan putusan pemberhentian sementara terhadap Nana Juwana sesuai dengan pasal 22 angka (1) UU No. 8 Tahun 2004 tentang perubahan atas UU No. 2 Tahun 1986 tentang Peradilan Umum yaitu Ketua, Wakil Ketua, dan Hakim Pemgadilan sebelum diberhentikan tidak dengan hormat sebagaimana dimaksud dalam pasal 20 angka (1) dapat diberhentikan sementara dari jabatannya oleh Ketua Mahkamah Agung. Terdapat perbedaan antara isi dari pasal tersebut dengan ketentuan dalam UU No. 22 Tahun 2004 tentang Komisi Yudisial. Dalam pasal 23 angka (2) jo. Angka (5) dijelaskan bahwa mengenai pemberhentian sementara disamakan dengan pemberhentian sehingga baik pemberhentian sementara maupun pemberhentian diusulkan oleh Katua Mahkamah Agung kepada Presiden. Sedangkan dalam UU No. 8 Tahun 2004 dijelaskan bahwa pemberhentian sementara merupakan mekanisme sebelum pemberhentian tidak dengan hormat sehingga dapat langsung dilakukan oleh Ketua Mahkamah agung. Adanya pertentangan antara 
pasal 22 angka (1) UU No. 8 Tahun 2004 dengan pasal 23 angka (3) jo. Angka (5) UU No. 22 Tahun 2004 dapat menimbulkan kesulitan dalam menentukan siapa yang berhak menjatuhi sanksi pemberhentian sementara terhadap hakim yang akan dijatuhi sanksi tersebut, apakah Ketua MA atau Presiden.

\section{Penutup}

\section{A. Kesimpulan}

Berdasarkan pertimbangan dari Komisi Yudisial dalam memberikan rekomendasi berupa sanksi pemberhentian sementara kepada Hakim Ketua Kasus Pilkada Depok, adalah diluar kewenangan dari Komisi Yudisial karena pada intinya yang diperiksa adalah mengenai kualitas putusan, baik dari segi pertimbangan hukum seperti ketepatan penerapan dan penafsiran hukum, kesesuaian antara pertimbangan hukum dan putusan, serta argumentasi hukum yang diutarakan oleh Majelis Hakim yang merupakan aspek teknis yudisial yang seharusnya diperiksa oleh Mahkamah Agung dan bukan oleh Komisi Yudisial. Sesuai tugasnya Komisi Yudisial hanya mempunyai dua kewenangan, yakni memeriksa etika hakim dan pencalonan hakim ke mahkamah agung. Sebenarnya ada satu pemeriksaan lagi yang dilakukan oleh Komisi Yudisial terkait dengan dugaan suap yang dilakukan Majelis Hakim tersebut. Mengenai dugaan suap, berdasarkan keterangan dari Hakim Ketua kasus Pilkada Depok bahwa dugaan tersebut tidak terbukti setelah Tim Pencari Fakta dari Komisi Yudisial melakukan pencarian fakta.

Dari pertimbangan yang diajukan oleh Komisi Yudisial, semuanya menyangkut materi perkara dan kesalahan dalam penerapan UU dan Hukum Acara dimana hal tersebut masuk dalam bentuk pengawasan yang terkait dengan kemampuan teknis yudisial hakim dalam menyelesaikan perkara. Dengan demikian telah terjadi pelampauan wewenang yang dilakukan oleh Komisi Yudisial dimana Komisi Yudisial telah melampaui yurisdiksi dari Mahkamah Agung sebagai suatu lembaga tertinggi dalam kekuasaan kehakiman yang wewenangnya adalah mengawasi jalannya peradilan di semua lingkungan peradilan serta menguji atau menilai tepat atau tidaknya suatu putusan yang dikeluarkan oleh badan peradilan dibawahnya. Seharusnya dengan adanya kesalahan-kesalahan dalam pengambilan putusan oleh Majelis Hakim PT Bandung terkait dengan sengketa Pilkada Depok, Komisi Yudisial menjadikannya sebagai bukti awal 
dugaan pelanggaran kode etik yang dilakukan oleh Majelis Hakim tersebut yaitu indikasi adanya penyuapan agar salah satu pihak dapat dimenangkan dalam perkara tersebut. Apabila ternyata banyak kejanggalan pada putusan sengketa Pilkada Depok, dapat dijadikan indikasi kuat adanya penyimpangan kewenangan dari Majelis Hakim tersebut demi memenangkan salah satu pihak dalams sengketa. Akan tetapi, oleh Komisi Yudisial adanya kesalahan dalam pengambilan putusan tersebut dijadikan dasar pengajuan rekomendasi kepada Mahkamah Agung untuk memberikan sanksi kepada kelima hakim yang memimpin sidang perkara sengketa Pilkada Depok.

Hal ini terjadi karena kurang jelasnya yurisdiksi kewenangan antara Lembaga Pengawasan Internal dalam hal ini Mahkamah Agung dan Lembaga Pengawasan Eksternal dalam hal ini Komisi Yudisial sehingga terjadi pelampauan wewenang atau "overlapping" yang dilakukan oleh Komisi Yudisial. Seandainya telah ada suatu aturan baku mengenai pembagian kewenangan pengawasan antara Mahkamah Agung dengan Komisi Yudisial, tentunya hal ini tidak akan terjadi. Pemeriksaan Hakim PT Bandung ini merupakan kerja pertama dari Komisi Yudisial dalam menjalankan wewenangnya untuk menegakkan kehormatan dan keluhuran martabat serta menjaga perilaku hakim dan dengan melihat hasil kerja dari Komisi Yudisial tersebut, adalah sangat mendesak untuk segera membuat aturan mengenai pembagian wewenang tersebut. jangan sampai timbul persepsi baru dalam masyarakat bahwa dengan adanya Komisi Yudisial maka telah muncul upaya hukum yang baru disamping upaya hukum terdahulu terhadap putusan pengadilan, seperti banding, kasasi dan Peninjauan Kembali (PK).

\section{B. Saran}

Perlu diperhatikan, bahwa pada dasarnya Komisi Yudisial dibentuk untuk membantu meringankan tugas dari Mahkamah Agung dalam melakukan rekruitmen Hakim Agung dan menegakkan kehormatan dan martabat serta menjaga perilaku hakim sehingga Mahkamah Agung dapat lebih fokus dalam menghasilkan suatu putusan yang berkualitas dan independen agar dapat mencapai tujuannya yaitu kepastian hukum dan keadilan dalam masyarakat. Berdasarkan wawancara dengan ASBIDWASBIN yaitu Bapak Ansyahrul, S.H., Mahkamah Agung pun tidak dapat menyalahkan proses pemeriksaan yang dilakukan oleh Komisi Yudisial dikarenakan pada dasarnya memang belum ada aturan yang menjelaskan hal-hal 
apa saja yang tidak boleh diperiksa oleh Komisi Yudisial. Lebih lanjut, diharapkan bahwa antara Mahkamah Agung sebagai lembaga pengawasan internal dan Komisi Yudisial sebagai lembaga pengawasan eksternal dapat tercipta suatu sinergi karena pada dasarnya kedua lembaga pengawasan ini memiliki tujuan dan misi yang sama yaitu untuk menjaga serta menegakkan kehormatan dan perilaku hakim. Sinergi antara kedua wujud pengawasan dapat terjadi jika telah ada aturan yang jelas mengenai batas kewenangan pengawasan masing-masing lembaga. Apabila tidak ada niat maupun kemauan untuk saling bekerja sama antara kedua lembaga pengawasan tersebut, reformasi di bidang hukum tidak akan mungkin bisa terwujud.

Sangat diperlukan untuk mengkaji ulang Undang-Undang maupun peraturan pelaksana yang memberi kewenangan kepada kedua lembaga pengawasan baik Mahkamah Agung (MA) maupun Komisi yudisial (KY) karena antara UU No. 4 tahun 2004 tentang kekuasaan kehakiman, UU No. 8 Tahun 2004 tentang Peradilan Umum sebagai payung kewenangan Mahkamah Agung dengan UU No. 22 Tahun 2004 tentang Komisi yudisial tidak mencerminkan adanya kesesuaian untuk saling mengisi dalam menjaga serta menegakkan perilaku hakim di Indonesia. Adanya beberapa ketentuan dalam peraturan tersebut yang saling bertentangan menimbulkan kesulitan melakukan pengawasan terhadap perilaku hakim sehingga terjadilah yang dinamakan tumpang tindih kewenangan antara keduanya. 


\section{Daftar Pustaka}

Ali. Achmad. Keterpurukan Hukum di Indonesia Penyebab dan Solusinya. Bogor: Ghatia Indonesia, 2005.

Effendi Lotulung. Paulus. "Kemandirian Kekuasaan Kehakiman Dalam Konteks Pembagian Kekuasaan dan Pertanggungan Jawab Politik". Makalah disampaikan pada seminar Hukum Nasional ke-VII dengan tema Reformasi Hukum Menuju Masyarakat Madani, Jakarta, 12-15 Oktober 1999.

Indonesia, Undang-Undang tentang Kekuasaan Kehakiman, UU No. 4 Tahun 2004, LN Tahun 2004 Nomor 8.

, Undang-Undang tentang Peradilan Umum, UU No. 8 Tahun 2004. LN Tahun 2004 Nomor 34. 1985

, Undang-Undang tentang Mahkamah Agung, UU No. 14 Tahun

. Peraturan Pemerintah mengenai Penilaian Pelaksanaan Pekerjaan Pegawai Negeri Sipil, PP No. 10 Tahun 1979.

- Peraturan Pemerintah mengenai Peraturan Disiplin Pegawai Negeri Sipil. PP No. 30 Tahun 1980.

- Perubahan Ketiga Undang-Undang Dasar Republik Indonesia, UUD 1945.

, Undang-Undang tentang Komisi Yudisial, UU Nomor 22 Tahun 2004, LN Tahun 2004 Nomor 89.

Mahkamah Agung RI. Naskah Akademis Dan Rancangan Undang-Undang Tentang Komisi Yudisial, Jakarta: MARI, 2003.

Mahkamah Agung RI. Kertas Kerja Pembaruan Sistem Pembinaan SDM Hakim, Jakarta: MARI, 2003.

Mahkamah Agung RI. Cetak Biru Pembaruan Mahkamah Agung, Jakarta: Mahkamah Agung RI, 2003.

Mahkamah Agung RI. Kertas Kerja Pembaruan Sistem Pendidikan dan Pelatihan Hakim, Jakarta: MARI, 2003.

Mahkamah Agung dan Lembaga Kajian dan Advokasi untuk Independensi Peradilan (LeIP). Kajian Pengembangan Sistem, Mekanisme Serta Tata Kerja Pengawasan, Penilaian Kualitas dan Kinerja Hakim, Jakarta: Mahkamah Agung RI, 2005. 
Marbun, B.N. Kamus Manajemen, Jakarta: Pustaka Sinar Harapan, 2003.

Mertokusumo, Sudikno et A. Pitlo. Bab-bab Tentang Penemuan Hukum, cet.1. Jakarta: PT. Citra Aditya. 1993.

Muhammad, Abdulkadir. Etika Profesi Hukum, Bandung: Citra Aditya Bakti. 2001.

Muqoddas, Muh Busyro. "Hubungan Antar Lembaga (Komisi Yudisial Berharap MA Responsif)", Kompas: Kamis, 29 September 2005.

Sarwoto. Dasar-Dasar Organisasi dan Management, Jakarta: Ghalia Indonesia.

Siagian, S.P. Filsafat Administrasi, Jakarta: Gunung Agung, 1990.

Sutiyoso, Bambang dan Sri Hastuti Puspitasari. Aspek-Aspek Perkembangan Kekuasaan Kehakiman di Indonesia, Yogyakarta: UII-Press, 2005.

Thohari, A. Ahsin. Komisi Yudisial dan Reformasi Peradilan, Jakarta: ELSAM, 2004.

Wiarda. Drie Typen Van de Rechtsvindings, Deventer: W.E.J - Tjeink Willink. 1999. 